\title{
Do perceived service value, quality, price fairness and service recovery shape customer satisfaction and delight? A practical study in the service telecommunication context
}

\author{
Haitham Alzoubi $^{\mathrm{a}}$, Muhammad Alshurideh ${ }^{\mathrm{b}}$, Barween Al Kurdi ${ }^{\mathrm{c}}$ and Mohammad Inairat ${ }^{\mathrm{a}}$
}

\author{
${ }^{b}$ University of Sharjah, United Arab Emirates \\ ${ }^{c}$ Amman Arab University, Jordan \\ C H R O N I C L E

\begin{tabular}{l}
\hline Article history: \\
Received November 29, 2019 \\
Received in revised format \\
January 31,2020 \\
Accepted February 202020 \\
Available online \\
February 202020 \\
\hline Keywords: \\
Customer Delight \\
Customer Satisfaction \\
Service Value \\
Service Quality \\
Service Recovery \\
Price Fairness
\end{tabular}

${ }^{a}$ Skyline University College, United Arab Emirates

\section{Introduction}

Organizations are interested in achieving high customer satisfaction and happiness in order to encourage them to repeat the purchase and to encourage others to do so (Famiyeh et al., 2018). Although customer satisfaction is not an ultimate goal for the organization, but it is one of the methods used to measure customer loyalty (Zameer et al., 2019) or to measure customer delight (Torres \& Kline, 2006; Hensher, 2014). Initially it is important to discuss what customer satisfaction and customer happiness mean and declare if both concepts differ. Customer satisfaction has been defined by Schiffman and Kanuk (2004) as the "individual's perception of the performance of the product or service in relation to his or her expectations" while Patterson (1997) declared that "customer delight involves going beyond satisfaction to delivering what can be best described as a pleasurable experience for the client". Accordingly, it can be elicited that customer delight and happiness express a stronger emotional status and denote a differ of a high psychological status than satisfaction and go beyond to include surprise and joy (Nadler, 1970; Kumar et al., 2001; Kangogo et al., 2013; Ahmed et al., 2016). 
It has been observed that the main benefit of satisfied customers is to spread a good and positive word of mouth about the organization and its products and/or services (Abdul Rehman, 2012; Alzoubi, et al., 2019) and practically increase the repeat purchase behavior (Alshurideh et al., 2012). Meanwhile, improving the customer satisfaction would improve the company image and the brand name image as well (Phi et al., 2018) as well as many scholars denoted that customer happiness tend to increase customer loyalty (Plassmann et al., 2007; Suki, 2014) and retaining a happy customer costs five time less than attracting a new customer (Albarq, 2013). However, a large number of satisfied customers is expected to improve the profitability in terms of increasing sales, and influence the overall growth of the company (Yalllapragada, 2017). Lately, customers delight and happiness start to appear in the emerging economies and legally some countries (for example, UAE) start adapting such concept heavily not only in delivering their governmental services but also in evaluating the quality of such services delivered. According to Torres and Kline (2006), during the last few years, the customer delight concept has been used recently in literature while it takes precedence over other concepts such as customer satisfaction. Both scholars mentioned that little number of studies have tackled the customer delight in different business topics such as hospitality industry. Thus. This study adds value to the knowledge by addressing the main factors affecting customer delight from service value perception, service quality perception, and service price fairness perception in addition to service recovery perception in the telecommunication industry. Organizations have used to measure customer satisfaction because it helps them determine whether their products/services meet the customer expectation or not, or whether the customers have better experience than their expectations do. Within the meanwhile, measuring customer delight helps firms know whether they are doing well or not, and to adjust their performance with the required improvement, which shift to meet customer expectations. This might help companies decide where they want to look ahead in terms of their both strategy and polices then monitoring their performance accordingly otherwise, they might end up losing the customers to the other competitors on the market (Alkalha et al., 2012; Shannak et al., 2012; Odunlami, et al., 2013).

UAE Etisalat Company started providing telecommunication services in 1963 in the UAE. While International Etisalat have operations in other 19 countries include East African and the Middle East, with over 135 million customers, and it is the 12th largest voice carrier in the world. Etisalat serve around 11.6 million customers in UAE. This study has come to assess the effect of four proposed factors including perceived service value, perceived service quality, perceived service recovery and perceived price fairness on both customer satisfaction and customer happiness at Etisalat Company in UAE.

There is no doubt that all organizations are interested in seeking to satisfy their customers and investigate the factors that make them happy. This study comes to serve the literature and practitioners by studying new factors that are used to test customer satisfaction and happiness, which are perceived service value, perceived service quality, perceived service recovery and perceived price fairness. However, a large number of studies have been done to investigate customer satisfaction and loyalty such as Alshurideh (2010). Nevertheless, this study used a set of new happiness determinants (e.g. perceived price fairness and perceived service recovery) within the telecommunication industry in one of the promising industries in the Middle East region. The study importance is clear despite the fact that not only many researches were found tackling the critical success factors of customer satisfaction and customer loyalty, but also there are only few focused on customer delight in telecommunication industry, especially in UAE (Yallapragada, 2017). That is because many scholars such as Patterson (1997) see customer delight as the most effective business indicator that increase customer retention rate. The next part introduces the literature that discussed each independent variable in more details.

\section{Literature review and hypotheses development}

\subsection{Perceived service value influence on both customer satisfaction and customer delight}

Many researchers have investigated the factors affecting customer satisfaction from different angles and a set of other studies provided empirical studies and frameworks to examine the satisfaction' determinants (Alshurideh et al., 2012; Alshurideh, 2014; Ammari et al., 2017; Al-dweeri et al., 2017). However, few studies were conducted to measure the impact of perceived service value on both customer satisfaction and customer delight. Marketing function is one of the core functions of any organization these days. Based on that, marketing can be considered as an important function since it has the most business-to-customer contact dimension. The core of successful marketing strategy and best business practice is to survey, understand, build, convey, and add value to customer that lead to customer satisfaction (Husnain \& Akhtar, 2015). Service oriented organizations should know the best ways to market their services/products and find the effective ways to communicate their differential values to customers, in order to deliver their services in a way to satisfy their needs (Tjiptono, 2002). Many scholars such as Nguyen, et al. (2018) claimed that marketing efforts and employees' training had great effects on customer satisfaction (Nguyen et al., 2018). Some of studies carried out found that service innovativeness, service reliability, service competitiveness and service consistency had significant impacts on customer satisfaction, whereas factors like operator's network/signal coverage, pricing, offering, fulfilment of customer demand, value added service, brand value and operators' contribution to society had more significant influence on the level of customer perceived value and satisfaction. Moreover, Rahman (2014) conducted a study in the telecommunications industry and assumed that customer satisfaction can be considered as one of the measures and indicators of service innovativeness, service reliability, service competitiveness, service consistency, signal coverage, reasonable price, quality of offering, customer demand fulfilment; value added service, brand value and operator's contribution to society. Moreover, a unique factor that was considered in Rahman's study was the operator's contribution to society and this factor was being considered important because at point 
of time, the image of the company is also associated with the accumulated benefits or value that the company deliver to the society level not just to customer level. Based on previous explanation, the proposed relationships between perceived value and both customer satisfaction and delight can be assumed as:

$\mathbf{H}_{1}$ : Perceived service value positively influences customer satisfaction.

$\mathbf{H}_{2}$ : Perceived service value positively influences customer delight.

\subsection{Perceived service quality influence on customer satisfaction and customer delight}

Some researchers such as Obeidat et al. (2012) and Alshurideh et al. (2017) developed a linkage between service quality and both customer satisfaction and customer loyalty but not that much publications link between perceived service quality effect on both customer satisfaction and customer delight. Arora and Narula (2018), for example, confirmed the impact of service quality on customer satisfaction and customer loyalty. In addition, Lai and Nguyen (2017) examined the factors affecting customer satisfaction and customer loyalty at telecommunications industry. Both scholars found that service quality, assurance, responsiveness, reliability, empathy and tangibility have some effects on and have positive relationships with both customer satisfaction and customer loyalty. A study has been conducted by Herington and Weaven (2007) about how to improve business-to-customer relations when providing high quality online banking services. The study denoted that providing high quality services to customers and making such customers perceived such quality leads to have highsatisfied customers, which in turn creates high level of loyalty, and such loyalty brings customers delight and happiness. This tends to increase the purchase volume per visit and escalate the purchase frequency as well. Accordingly, companies need to understand in which way the customer will perceive the quality of its products and services (Al-Dmour \& AlShraideh, 2008; Castaneda, 2011; Obeidat et al., 2012). Based on previous explanation, the proposed relationships between perceived service quality and both customer satisfaction and delight can be assumed as:

$\mathbf{H}_{3}$ : Perceived service quality positively influences customer satisfaction.

$\mathbf{H}_{4}$ : Perceived service quality positively influences customer delight.

\subsection{Perceived service recovery influences on customer satisfaction and customer delight}

Ampomah (2012) conducted a study in the telecommunications industry in Ghana. The scholar pointed out the fact that the level of customer satisfaction is affected by five main factors, which includes service quality, price fairness, service recovery, brand image and customer orientation toward the company and its employees. Form such founding; service recovery is an important element of customer satisfaction and delight that need to be discussed in details. Maxham (2001) defined Service failure as "any service-related mishaps or problems (real and/or perceived) that occur during a consumer's experience with the firm". While service recovery is defined by Grönroos (1988) as, "the service provider's action when something goes wrong". It is mentioned in different situations that it is important to give more lights on how service failure recovery affect customer satisfaction and delight. Duffy et al. (2006) provide an initial study about the relationship between customer satisfaction and service recovery strategies in retail banks in USA. The scholars addressed hundreds of customers with respect to their demographical characteristics and levels of satisfaction in addition to using different types of recovery strategies and service recovery employees. The study found that there are no significant differences in satisfaction and recovery strategy linked to customers' gender and age or customer relationship longevity with bank. However, the study found that customer satisfaction level differs and strongly affected by the type of the recovery strategy used. The study indicated that the recovery efforts exerted by employees are best to be used toward empathic listening to customers' problems then fixing their problem better than using apologizing or atonement procedures. Regarding service recovery influence and customer delight. Not that much studies found linking such terms together. Barnes et al. (2011) declared that service failure recovery is important and, in most cases, take greater importance from customer perspectives than the delivered services itself. Buttle and Burton (2002) declared that when service failures happen, the recovery procedures and process has greater effect on customer loyalty better than the original service provided. Both scholars mentioned that customers' perception of fairness occurs when an organization has success recovery strategies and programs. According to Hart et al. (1990), "a good recovery can turn angry, frustrated customers into loyal ones. It can, in fact, create more goodwill than if things had gone smoothly in the first place" (Hart et al., 1990, p. 148). Accordingly, service recovery can influence customers' emotions and psychological status according to Obeidat et al. (2019). Based on the above explanation, the proposed relationships between perceived service recovery influence and both customer satisfaction and delight can be assumed as:

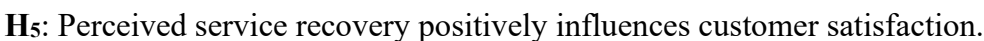

H6: Perceived service recovery positively influences customer delight.

\subsection{Perceived service price fairness influences on customer satisfaction and customer delight}

A study taken up by Khan and Afsheen (2012) who investigated the factors that influence customer satisfaction in the telecommunications industry setting declared that satisfaction is shaped by a number of influencers which are which are customer service, price fairness, sales promotion, coverage, signal strength and promotion. The results indicated that customers are more concerned with price fairness and signal strength. Signal strength can be referred to one of the service 
quality technical determinants because customer expects the company to provide both strong signals and wide coverages (Neupane, 2014). However, perceived service price fairness influences has not taken much interests from scholars and can be considered one of the service ethical dimensions that need more practical tests (Alshurideh et al., 2017; Alshurideh et al., 2016; Salloum \& Al-Emran, 2018). Some studies (e.g. Romdonny \& Rosmadi, 2019) focused on the importance of the relationship between service quality and price to be part of the factors that lead to customer satisfaction. Keep in mind that it is not easy for customers to be convinced whether the value taken equal to the price given, simply because customers always compare the prices charged with similar competitors' products or services (Ilieska, 2013; Alshurideh, 2016; Salloum et al., 2018). However, customers became more and more concern about the effectiveness of the marketing mix efforts, especially for the services and its unique characteristics, which require enhancing the way of communicating with customers, and updating them with right information in the right time and truthfully (John, 2003). In the service oriented organizations, it has been confirmed in different situations that price of the service is considered to be one of the main two elements that affect heavily the customers purchasing decision which are quality and price. Moreover, price, in a way or another, thought to be a determinant of the service quality (Kaura, et al., 2014). Nevertheless, generally, it can be assumed that the service price, which should add a perceived value to customer, has an effect on customer satisfaction and customer loyalty positively (Toncar et al., 2010). To add more, price has a significant impact on customer's judgment on the service and customer's purchase decision, so price structure would be from the main marketing decision that need to be considered with care while it affects customer satisfaction (Salvador et al., 2006; Alshurideh et al., 2018). Based on the above explanation, the proposed relationships between perceived services price fairness and both customer satisfaction and delight can be assumed as:

H6: Perceived service price fairness positively influences customer satisfaction.

H8: Perceived service price fairness positively influences customer delight.

\subsection{Customer satisfaction influences customer delight}

Torres and Kline (2006) studied how effective management of customer relation can affect customer satisfaction, delight, and their interrelated antecedents. The study declared that customer delight could be considered one of the better concepts that can be used to measure customer relationship management even better than customer satisfaction while it tends to generate positive general feeling about the organization performance especially when such organizations tend to have better acknowledgments of customer relationship process. Delight found to produce more word-of-moth communications, which in turn influence loyalty and increase customer loyalty at last. Some scholars pointed out that customer satisfaction, delight should be planned strategically, and management should offer all possible means to achieve them. In addition, Marketing mix strategy which be implemented by any organization should first going through customer satisfaction. Which means that organization should discover the customer needs before they prepare and set their marketing mix strategy. Solimun and Fernandes (2018) found that marketing mix strategy has a significant impact on customer satisfaction. That means the marketing mix strategy is an indicator and would be the customer satisfaction determination (Caruana, 2002). Based on the above explanation, the proposed relationships between customer satisfaction and customer delight can be assumed as:

\section{H9: Customer satisfaction positively influences customer delight.}

The study model gives a brief view of the proposed relationships between the study factors as seen in Fig.1 as follows,

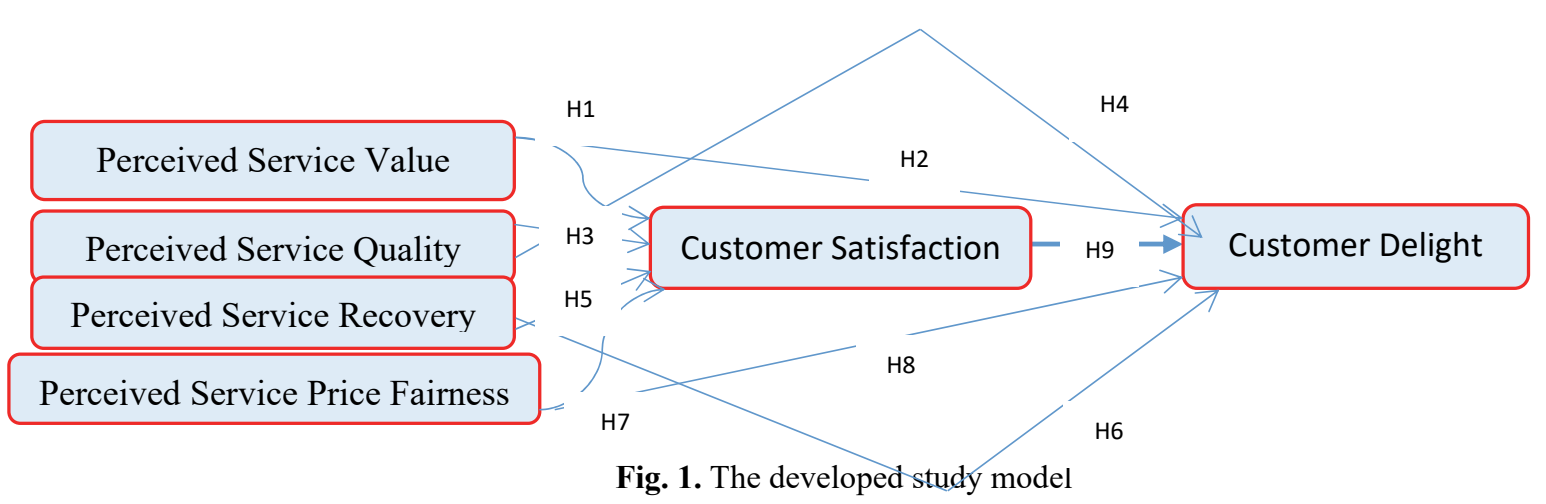

\section{Methodology}

The sample for the study has been selected to be of (420) respondents out of all customers of the all 28 branches of Etisalat company in Dubai. The sample has been selected randomly based on cluster random sampling technique so that branch of Etisalat-Dubai has an equal number of represents' customers being selected in the sample (Brown et al., 2003; Carrillat et al, 2007). The process of data collection last for one month as of one visit per week peer branch, each visit in different time. Moreover, all customers of Etisalat visiting the targeted branch had an equal chance of being selected in the sample. A (350) valid questionnaires were used for the purpose of model analysis and hypotheses testing. 
Table 1

Descriptive analysis for factors affecting customer satisfaction and customer loyalty

\begin{tabular}{|c|c|c|c|}
\hline Study variables & Rank & Mean & Std. \\
\hline Perceived Service Value & 6 & 2.48 & .891 \\
\hline Perceived Service Quality & 2 & 2.91 & .967 \\
\hline Perceived Service Recovery & 5 & 2.54 & .883 \\
\hline Perceived Price Fairness & 1 & 3.01 & .923 \\
\hline Customer Satisfaction & 4 & 2.63 & .945 \\
\hline Customer Delight & 3 & 2.78 & .962 \\
\hline
\end{tabular}

Table 1 shows the descriptive analysis that rank the importance of study variables. Respondents' perceptions indicate the importance and rank given toward study variables. The "Perceived Service Price" got the highest importance rank with mean (3.01) and Std. (0.923), followed by "Perceived Service Quality" with mean of (2.91) and Std. of (0.967). After that comes, "Customer Satisfaction and Customer delight" with means of (2.63: 2.78) and Std(s) of (0.954: 0.962) respectively. The last two variables in importance rank are "Perceived Service Recovery and Perceived Service Value" with means of (2.48: 2.54) and Std(s) of (0.891: 0.883) respectively. The factor analysis CFA/MSE have been used to assess the construct validity of the measurement's study, as it shows the extent to which a set of measured items actually reflect the theoretical latent construct in which they are designed to measure as leaded by Al Kurdi (2016); S A Salloum \& Shaalan, 2018; Salloum et al. 2019; and Alshurideh et al. (2019). Table 2 shows results of measurement model Convergent validity. It shows and combine the values of the factor loading, and Composite reliability (CR) with Average Variance Extracted (AVE), and all values of the study model are significant.

Table 2

Model Convergent validity

\begin{tabular}{|c|c|c|c|c|}
\hline Constructs & Items & Loading & $\mathrm{CR}$ & AVE \\
\hline \multirow{3}{*}{ Perceived Price Fairness (PPF) } & PPF1 & 0.912 & \multirow{3}{*}{0.937} & \multirow{3}{*}{0.832} \\
\hline & PPF2 & 0.909 & & \\
\hline & PPF3 & 0.914 & & \\
\hline \multirow{3}{*}{ Perceived Service Quality (PSQ) } & PSQ1 & 0.875 & \multirow{3}{*}{0.905} & \multirow{3}{*}{0.761} \\
\hline & PSQ2 & 0.906 & & \\
\hline & PSQ3 & 0.835 & & \\
\hline \multirow{3}{*}{ Perceived Service Recovery (PSR) } & PSR1 & 0.913 & \multirow{3}{*}{0.911} & \multirow{3}{*}{0.774} \\
\hline & PSR2 & 0.854 & & \\
\hline & PSR3 & 0.871 & & \\
\hline \multirow{3}{*}{ Perceived Service Value(PSV) } & PSV1 & 0.901 & \multirow{3}{*}{0.905} & \multirow{3}{*}{0.760} \\
\hline & PSV2 & 0.852 & & \\
\hline & PSV3 & 0.861 & & \\
\hline \multirow{3}{*}{ Customer Satisfaction(CS) } & $\mathrm{SC} 1$ & 0.905 & \multirow{3}{*}{0.904} & \multirow{3}{*}{0.759} \\
\hline & $\mathrm{SC} 2$ & 0.830 & & \\
\hline & $\mathrm{SC} 3$ & 0.877 & & \\
\hline \multirow{3}{*}{ Customer delight (CD) } & CD1 & 0.889 & \multirow{3}{*}{0.921} & \multirow{3}{*}{0.795} \\
\hline & CD2 & 0.881 & & \\
\hline & CD3 & 0.904 & & \\
\hline
\end{tabular}

All AVE values of the latent variable are higher than the squared correlation between the latent variable and all other variables which means that our latent variable explain better the variance of their own indicators than the variance of other latent variables, so the study model is valid (Chin, 2010; Alshurideh. 2019).

Table 3

Latent Variable Correlation

\begin{tabular}{rrrrrrr}
\hline & PPF & PSQ & PSR & PSV & CS & \\
\hline PPF & $\mathbf{0 . 8 9 2}$ & & & & \\
PSQ & 0.862 & $\mathbf{0 . 8 7 1}$ & $\mathbf{0 . 8 7 2}$ & $\mathbf{0 . 8 7 2}$ & \\
PSR & 0.737 & 0.830 & 0.871 & 0.812 & 0.865 & $\mathbf{0 . 9 1 2}$ \\
PSV & 0.810 & 0.814 & 0.836 & 0.844 & 0.804 \\
CS & 0.704 & 0.822 & $\mathbf{0 . 8 8 0}$ \\
CD & 0.776 & C
\end{tabular}

Boldface values are Variable correlation- Root square of AVE

Table 3 shows the Correlation Cross loading is the loading of an indicator on its assigned latent variable and should be higher than its loadings on all other latent variables. It shows that load more strongly on their own constructs in the model, which indicates a positive and strong relationship between the study variables.

\section{Hypothesis Testing and Discussion}

Based on the results obtained from the respondents for the study variables. Correlation, Regression and ANOVA analysis used to test the hypotheses. Table 4 and 5 illustrate a positive relationship between perceived service value (PSV) on both customer satisfaction (CS) and customer delight (CD), indicated by ( $\mathrm{r}=0.604$ and $\mathrm{r}=608)$, respectively. 
Table 4

Correlation, ANOVA and Regression analysis to Customer satisfaction and Customer loyalty

\begin{tabular}{|c|c|c|c|c|c|c|c|c|c|}
\hline DV & $\mathbf{r}$ & $r^{2}$ & $\mathbf{F} * * *$ & DF & Sig* & $\beta$ & & $t * *$ & Sig* \\
\hline \multirow[b]{2}{*}{ PSV } & \multirow[b]{2}{*}{0.604} & \multirow[b]{2}{*}{0.367} & \multirow[b]{2}{*}{9.823} & 1 & \multirow[b]{2}{*}{.000} & (Constant) & 1 & 2.876 & .0000 \\
\hline & & & & $\begin{array}{l}349 \\
350\end{array}$ & & $\mathrm{CS}$ & 0.501 & 3.089 & .0003 \\
\hline \multirow[t]{2}{*}{ PSV } & \multirow[t]{2}{*}{0.608} & \multirow[t]{2}{*}{0.341} & \multirow[t]{2}{*}{9.827} & $\begin{array}{c}1 \\
349\end{array}$ & \multirow[t]{2}{*}{.000} & (Constant) & I & 2.876 & .0000 \\
\hline & & & & 1 & & CD & 0.480 & 2.86 & .0002 \\
\hline \multirow[b]{2}{*}{ PSQ } & \multirow[b]{2}{*}{0.514} & \multirow[b]{2}{*}{0.264} & \multirow[b]{2}{*}{21.443} & 1 & \multirow[b]{2}{*}{.000} & (Constant) & 1 & 2.966 & .0002 \\
\hline & & & & $\begin{array}{l}349 \\
350\end{array}$ & & CS & 0.586 & 3.009 & .0006 \\
\hline \multirow[b]{2}{*}{ PSQ } & \multirow[b]{2}{*}{0.512} & \multirow[b]{2}{*}{0.262} & \multirow[b]{2}{*}{21.439} & 1 & \multirow[b]{2}{*}{.000} & (Constant) & 1 & 2.966 & .0002 \\
\hline & & & & $\begin{array}{l}349 \\
350\end{array}$ & & $\mathrm{CD}$ & 0.581 & 3.005 & .0004 \\
\hline \multirow[t]{2}{*}{ PSR } & \multirow[t]{2}{*}{0.463} & \multirow{2}{*}{0.241} & \multirow{2}{*}{16.326} & $\begin{array}{c}1 \\
349\end{array}$ & \multirow[t]{2}{*}{.000} & & 1 & 2.746 & .0001 \\
\hline & & & & 350 & & $\mathrm{CS}$ & 0.109 & 2.719 & .0002 \\
\hline \multirow[b]{2}{*}{ PSR } & \multirow[b]{2}{*}{0.460} & \multirow[b]{2}{*}{0.238} & \multirow[b]{2}{*}{16.323} & 1 & \multirow[b]{2}{*}{.000} & (Constant) & I & 2.741 & .0002 \\
\hline & & & & $\begin{array}{l}349 \\
350\end{array}$ & & $\mathrm{CD}$ & 0.106 & 2.716 & .0003 \\
\hline \multirow{2}{*}{ PPF } & \multirow{2}{*}{0.600} & \multirow{2}{*}{0.339} & \multirow{2}{*}{9.824} & $\begin{array}{c}1 \\
349\end{array}$ & \multirow{2}{*}{.000} & (Constant) & 1 & 2.874 & .0000 \\
\hline & & & & 350 & & CS & 0.480 & 3.050 & .0001 \\
\hline PPF & 0.445 & 0.198 & 8.903 & $\begin{array}{c}1 \\
349\end{array}$ & .000 & (Constant) & I & 2.876 & .0001 \\
\hline & & & & 350 & & $C D$ & 0.298 & 2.939 & .0000 \\
\hline & & & & 1 & & (Constant) & 1 & 2.988 & .0002 \\
\hline CS & 0.584 & 0.341 & 31.903 & $\begin{array}{l}349 \\
350\end{array}$ & .000 & $\mathrm{CD}$ & 0.498 & 3.123 & .0000 \\
\hline
\end{tabular}

Table 5

Hypotheses testing results

\begin{tabular}{clllll}
\hline Hy number & Effect Direction & Results & Hy number & Effect Direction & Results \\
\hline H1 & PSV effect on CS & Supported & H6 & PSR effect on CD & Supported \\
H2 & PSV effect on CD & Supported & H7 & PPF effect on CS & Supported \\
H3 & PSQ effect on CS & Supported & H8 & PPF effect on CD & Supported \\
H4 & PSQ effect on CD & Supported & H9 & CS effect on CD & Supported \\
H5 & PSR effect on CS & Supported & & & \\
\hline
\end{tabular}

The $\mathrm{r}^{2}$ for both factors were 0.367 and 0.341 , which means that $(0.367)$ of changes in customer satisfaction can be associated to changes in PSV and (0.341) change in customer delight can be associated to change in changes in PSV. Moreover, it has been found out that F-value for both factors were (9.823 and 9.287) and both were significant at level of significance of (0.05). In addition, both statistics of $t$ values were 3.089 and 2.876 and $\beta$ values were 0.501 and 0.480 , and both were significant at (0.05). Therefore, the results support both hypotheses number one and two, which confirm the impact of PSV on both CS and CD. Regarding the relationship between perceived service quality (PSQ) effect on both customer satisfaction (CS) and customer delight (CD), results shown in Table 4 illustrate positive relationships between perceived service quality (PSQ) and both customer satisfaction (CS) and customer delight (CD), indicated by r values of 0.514 and 0.512 in order. The $\mathrm{r}^{2}$ values for both factors were 0.264 and 0.262 , which means that 0.246 of changes in customer satisfaction can be associated to changes in PSQ and 0.262 changes in customer delight can be associated to change in PSQ. Moreover, it has been found out that F-value for both factors were (21.443 and 21.439) and both were significant at level of significance of (0.05). Moreover, both statistics of $t$ values were 3.009 and 3.005 and $\beta$ values were 0.586 and 0.581 , which both were significant at (0.05). Therefore, the results support both hypotheses number three and four, which confirm the impact of PSQ on both CS and CD. About the relationship between perceived service recovery (PSR) effect on both customer satisfaction (CS) and customer delight (CD), results shown in Table 4 illustrate positive relationships between perceived service recovery (PSR) and both customer satisfaction (CS) and customer delight (CD), indicated by $r$ values of 0.463 and 0.460 in order. The $\mathrm{r}^{2}$ values for both factors were 0.241 and 0.238 , which means that 0.241 of changes in CS can be associated to changes in PSR and 0.238 changes in CD can be associated to change in PSR. Moreover, it has been found out that F-value for both factors were (16.326 and 16.323) and both were significant at level of significance of $(0.05)$. In addition, both statistics of $t$ values were 2.719 and 2.719 , and $\beta$ values were 0.109 and 0.106 , which both were significant at (0.05). Therefore, the results support both hypotheses number five and six, which confirm the impact of PSR on both CS and CD. About the relationship between perceived price fairness (PPF) effect on both customer satisfaction (CS) and customer delight (CD), results shown in Table 4 illustrate positive relationships between perceived price fairness (PPF) and both customer satisfaction (CS) and customer delight (CD), indicated by $r$ values of 0.60 and 0.445 in order. The $r^{2}$ values for both factors were 0.339 and 0.198 , which means that 0.339 of changes in CS can be associated to changes in PPF and 0.198 changes in CD can be associated to change in PPF. Moreover, it has been found out that F-value for both factors were (9.824 and 9.803) and both were significant at level of significance of (0.05). In addition, both statistics of t values were 
0.480 and 0.298 , and $\beta$ values were 0.480 and 0.106 , which both were significant at $(0.05)$. Therefore, the results support both hypotheses number seven and eight, which confirm the impact of bot PPF on both CS and, CD. On the same regard, a positive relationship between customer satisfaction (CS) and customer delight (CD), indicated by r value of 0.584 while the $\mathrm{r}^{2}$ value was 0.341 , which means that 0.341 of changes in $C D$ can be associated to changes in CD. In addition, it has been found out that $F$ value was (31.903) and it was significant at level of significance of (0.05). Additionally, the statistic $t$ value was 3.123 and $\beta$ value was 0.498 , which was significant at $(0.05)$. Therefore, it can be assumed that the hypothesis number nine is confirmed, which prove the impact of customer satisfaction on customer delight.

\section{Results discussion}

Results of this study have found a positive and strong relationship between the study variables. Moreover, hypotheses testing results confirm the impact of perceived service value, perceived service quality, perceived service recovery and perceived service price fairness on both customer satisfaction and customer delight, and results also assure the positive impact of customer satisfaction in turn on customer delight. Tam (2004) confirmed the effect of perceived service value on customer satisfaction and noted that much studies found giving deep lights on the effect of customer perceived serve value on customer delight while this study confirms such relation. To add more, the results of this study comes in line with other studies such as that conducted by Romdonny and Rosmadi (2019) who found a positive effect of service quality on customer satisfaction. Also, Herington and Weaven (2007) found that delight customers were found having high level of perceived service quality. Such results come in line with what Hume and Sullivan (2010) and Jhandir (2012) who uncovered statistical proofs of the effect of both perceived service value and perceived service quality on customer satisfaction. Based on this, it can be declared that most of study sample were satisfied with the quality of services that provided by Etisalat and perceive it is value right and some of them even stated the fact that Etisalat and its staff is quite hospitable due to which they have been contracted with the company for long time and renew their contracts accordingly. This issue has been confirmed and aligned with other study found (e.g. Alshurideh. 2010; Alshurideh. 2016; Alshurideh. 2017; Nguyen, et al., 2018; Alshurideh. 2019; Salloum et al., 2018). Moreover, this study declared and confirmed the positive effect of perceived service recovery on both customer satisfaction and customer delight. Komunda and Osarenkhoe (2012) who mentioned that perceived service recovery makes customers express positive world-of-mouth and affect positively both customer satisfaction and customer loyalty have discovered this matter. However, not that many studies were found testing the relationship between perceived service recovery and customer delight. Such relationship was tested and confirmed practically in this study. Other studies come close to study such issue such as that done by Duffy et al. (2006) who found that perceived service recovery was perceived to be effective on loyal customers in addition to Andreassen (2001) who declared that excellent service recovery help in minimizing customers' complaints and restore their image and intent. Thus, studying the effect of perceived service recovery on customer delight is one of the unique contributions of this study. Another major issue in this study is tackling the effect of perceived price fairness on both customer satisfaction and customer delight. There is a large number of studies that investigate the effect of service price on customer satisfaction (e.g. Kaura, et al., 2014). However, studying the effect of perceived service price on both customer satisfaction and customer delight does not get much interest from scholars. Jin et al. (2016) studied if there is a relationship between price fairness, image and loyalty in the hospitality setting. The study found that there is a positive effect of image on customer loyalty with the intervening effect for customer delight, price fairness and service quality. Accordingly, price fairness can be considered as one of the ethical dimensions that companies need to be considered with care when planning their products/services offerings and such elements needs more investigation specially the fairness of the promotional price (Alshurideh et al., 2016; Alshurideh et al., 2017; Alshurideh et al., 2018; Salloum \& Shaalan, 2018a). Respondents agreed that perceived price fineness is an important factor for them because they feel that value for the service provided should be met with faire price to make their customers satisfy and delight. On the other hand, the study respondents do not feel that the company is overcharging them for the mobile service provided but it is important to make them feel that such price is coming within their expectation and fit the level of delivered service quality (Toncar et al., 2010). To add more, Khuong and Dai (2016) investigated a set factors that affecting customer satisfaction at telecommunications industry including reliability, comfort, information, responsiveness, dignity, tangibility and price, and they found that customer satisfaction was positively related with price and comfort level of the customer, and rest of the factors could be overlooked if these were as per the expectations of the customer. Some studies have reviewed and confirmed the linkage between customer satisfaction and customer loyalty, as customer satisfaction influence and lead customer loyalty (Arora \& Narula, 2018; Nguyen, et al., 2018; Phi, et al., 2018). In addition, Shafei and Tabaa (2016) investigated the same linkage in the telecommunications industry and found that there is a positive effect of customer satisfaction on customer loyalty. Many other studies proposed the same assumption regarding the positive effect of customer satisfaction and how it leads and contribute to customer loyalty (Dutta et al., 2017; Keshavarz \& Jamshidi, 2018). However, not that many studies investigated the effect of customer satisfaction on customer delight as this study did. This study checked the effect of customer satisfaction on customer delight and confirmed such relation positively. Such relation has been confirmed as many other scholars found such as Torres and Kline (2013) who provided proofs about the positive relationship between customer satisfaction and customer delight.

\section{Conclusion}

The main purpose behind conducting this study was to explore factors affecting customer satisfaction and customer delight toward the products and services offered within the mobile phone setting. This study is important because it tackled one of 
the main problems than mobile service providers face these days which is the high level of customer attrition rate as declared by Al Dmour et al. (2014), Alshurideh (2014), Alshurideh et al. (2015), Alshurideh (2016). It is important to keep the customers satisfied since this is one of the main reasons to support the company existence (Alshurideh, 2016a,2016b; Muhammad Alshurideh et al., 2019). The study investigated what if perceived service value, perceived service quality, perceived service recovery and perceived price fairness can be considered as critical success factors to customer satisfaction and customer delight. Based on results found, all proposed relations were confirmed and proofed positively. This study has been taken up to have better picture about both customer satisfaction and delight and data collected from customers at all 28 main branches of Etisalat mobile service provider in Dubai-UAE. This study may help organizations who operate on the telecommunications industry make certain improvements in their services to enhance and improve customer satisfaction and their delight especially when the study investigates new delight and satisfaction drivers for the first time such as perceived price fairness, perceived service recovery and perceived service value. Such factors need more investigation specially when connecting price fairness perception with other internal service quality dimension such as empathy, reliability and assurance (Elsamen \& Alshurideh, 2012) or E-service quality dimensions those discussed by Al-dweeri et al. (2017) and customer commitment (Ammari et al., 2017)

\section{References}

Abdul Rehman, A. (2012). Customer satisfaction and service quality in Islamic banking. Qualitative Research in Financial Markets, $4(2 / 3), 165-175$.

Ahmed, U., Majid, A., \& Zin, M. L. M. (2016). HR moderating HR: Critical link between developmental HR practices and work engagement in a moderated model. Management Review: An International Journal, 11(2), 4-22.

Albarq, A. N. (2013). Applying a SERVQUAL model to measure the impact of service quality on customer loyalty among local Saudi banks in Riyadh. American Journal of Industrial and Business Management, 3(8), 700-707.

Al-Dmour, H., \& Al-Shraideh, M. T. (2008). The influence of the promotional mix elements on Jordanian consumer's decisions in cell phone service usage: An analytical study. Jordan Journal of Business Administration, 4(4), 375-392.

Al Dmour, H., Alshurideh, M., \& Shishan, F. (2014). The influence of mobile application quality and attributes on the continuance intention of mobile shopping. Life Science Journal, 11(10), 172-181.

Al-dweeri, R. M., Obeidat, Z. M., Al-dwiry, M. A., Alshurideh, M. T., \& Alhorani, A. M. (2017). The impact of e-service quality and eloyalty on online shopping: moderating effect of e-satisfaction and e-trust. International Journal of Marketing Studies, 9(2), 92-103.

Alkalha, Z., Al-Zu'bi, Z., Al-Dmour, H., Alshurideh, M., \& Masa'deh, R. (2012). Investigating the effects of human resource policies on organizational performance: An empirical study on commercial banks operating in Jordan. European Journal of Economics, Finance and Administrative Sciences, 51(1), 44-64.

AL Kurdi, B. (2016). Healthy-Food Choice and Purchasing Behaviour Analysis: An Exploratory Study of Families in the UK (Doctoral dissertation, Durham University).

Ammari, G., Alkurdi, B., Alshurideh, A., \& Alrowwad, A. (2017). Investigating the impact of communication satisfaction on organizational commitment: a practical approach to increase employees' loyalty. International Journal of Marketing Studies, 9(2), 113-133.

Andreassen, T. W. (2001). From disgust to delight: do customers hold a grudge?. Journal of service research, 4(1), 39-49.

Alshurideh, M. (2010). Customer service retention-A behavioural perspective of the UK mobile market (Doctoral dissertation, Durham University).

Alshurideh, M. (2010). A behavior perspective of mobile customer retention: An exploratory study in the UK Market. The End of the Pier? Competing perspectives on the challenges facing business and management British Academy of Management BrightonUK. British Academy of Management, 1-19.

Alshurideh, M. (2014). The Factors Predicting Students' Satisfaction with Universities' Healthcare Clinics' Services: A Case-Study from the Jordanian Higher Education Sector. Dirasat: Administrative Sciences, 161(1524), 1-36.

Alshurideh, M. T. (2014). A qualitative analysis of customer repeat purchase behaviour in the UK mobile phone market. Journal of Management Research, 6(1), 109-125.

Alshurideh, M. T. (2016). Is customer retention beneficial for customers: A conceptual background. Journal of Research in Marketing, 5(3), 382-389.

Alshurideh, M. (2016). Scope of Customer Retention Problem in the Mobile Phone Sector: A Theoretical Perspective. Journal of Marketing and Consumer Research, 20, 64-69.

Alshurideh, M. T. (2016). Exploring the main factors affecting consumer choice of mobile phone service provider contracts. International Journal of Communications, Network and System Sciences, 9(12), 563-581.

Alshurideh, M. T. (2016). Is customer retention beneficial for customers: A conceptual background. Journal of Research in Marketing, 5(3), 382-389.

Alshurideh, M. T. (2017). A theoretical perspective of contract and contractual customer-supplier relationship in the mobile phone service sector. International Journal of Business and Management, 12(7), 201-210.

Alshurideh, D. M. (2019). Do electronic loyalty programs still drive customer choice and repeat purchase behaviour?. International Journal of Electronic Customer Relationship Management, 12(1), 40-57.

Alshurideh, M. Al-Hawary, S., Mohammad, A., Mohammad, A., Al Kurdi, B. (2017). The Impact of Islamic Bank's Service Quality Perception On Jordanian Customer's Loyalty. Journal of Management Research, 9(2), 139-159.

Alshurideh, M., Al Kurdi, B., Abu Hussien, A., \& Alshaar, H. (2017). Determining the main factors affecting consumers' acceptance of ethical advertising: A review of the Jordanian market. Journal of Marketing Communications, 23(5), 513-532.

Alshurideh, M., Al Kurdi, B., Abumari, A., \& Salloum, S. (2018). Pharmaceutical Promotion Tools Effect on Physician's Adoption of Medicine Prescribing: Evidence from Jordan. Modern Applied Science, 12(11), 210-222.

Alshurideh, M., Al Kurdi, B., \& Salloum, S. A. (2019, October). Examining the Main Mobile Learning System Drivers' Effects: A Mix Empirical Examination of Both the Expectation-Confirmation Model (ECM) and the Technology Acceptance Model (TAM). In International Conference on Advanced Intelligent Systems and Informatics (pp. 406-417). Springer, Cham. 
Alshurideh, M., Al Kurdi, B. H., Vij, A., Obiedat, Z., \& Naser, A. (2016). Marketing ethics and relationship marketing-An empirical study that measure the effect of ethics practices application on maintaining relationships with customers. International Business Research, 9(9), 78-90.

Alshurideh, M., Bataineh, A., Alkurdi, B., \& Alasmr, N. (2015). Factors affect mobile phone brand choices-Studying the case of Jordan universities students. International Business Research, 8(3), 141-155.

Alshurideh, M., Masa'deh, R., \& Alkurdi, B. (2012). The effect of customer satisfaction upon customer retention in the Jordanian mobile market: An empirical investigation. European Journal of Economics, Finance and Administrative Sciences, 47(12), 69-78.

Alshurideh, M. Salloum, S., Al Kurdi, B., Abdel Monem, A., Shaalan. K. (2019). Understanding the Quality Determinants that Influence the Intention to Use the Mobile Learning Platforms: A Practical Study. International Journal of Interactive Mobile Technologies (IJIM), 13(11), 157-183.

Alzoubi, H., Abdo M., Al-Gasaymeh, A. \& Alzoubi, A. (2019). An empirical study of e-Service quality and its impact on achieving a value added. Journal of Business and Retail Management Research (JBRMR), 13(4), 138-145.

Ammari, G., Alkurdi, B., Alshurideh, A., \& Alrowwad, A. (2017). Investigating the impact of communication satisfaction on organizational commitment: a practical approach to increase employees' loyalty. International Journal of Marketing Studies, 9(2), 113-133.

Ampomah, Y. K. (2012). Factors Affecting Customer Satisfaction and Preference in The Telecommunications Industry: A Case Study of MTN GHANA, Unpublished Master Thesis, Kwame Nkrumah University of Science and Technology, GHANA.

Arora, P., \& Narula, S. (2018). linkage between service quality, customer satisfaction and customer loyalty: A literature Review. the IUP Journal of Marketing Management, 17(4), 30-53.

Barnes, D. C., Ponder, N., \& Dugar, K. (2011). Investigating the key routes to customer delight. Journal of Marketing Theory and Practice, 19(4), 359-376.

Brown, P., Hesketh, A. \& Williams, S. (2003). Employ ability in a knowledge-driven economy. Journal of Education and Work, 16(2), 107-126.

Buttle, F., \& Burton, J. (2002). Does service failure influence customer loyalty?. Journal of Consumer Behaviour: An International Research Review, 1(3), 217-227.

Carrillat, F.A., Jaramillo, F. \& Mulki, J.P. (2007). The validity of the SERVQUAL and SERVPERF scales: A meta-analytic view of 17 years of research across five continents. International Journal of Service Industry Management, 18(5), 472-490.

Caruana, A. (2002). Service loyalty the effects of service quality and the mediating role of customer satisfaction. European Journal of Marketing, 36(7/8), 811-828.

Duffy, J. A. M., Miller, J. M., \& Bexley, J. B. (2006). Banking customers' varied reactions to service recovery strategies. International Journal of Bank Marketing, 24(2), 112-132.

Dutta, S., Chauhan, R. \& Chauhan, K. (2017). Factors Affecting Customer Satisfaction of Online Travel Agencies India. Tourism and Hospitality Management, 23(2), 267-277.

ELSamen, A. A., \& Alshurideh, M. (2012). The impact of internal marketing on internal service quality: A case study in a Jordanian pharmaceutical company. International Journal of Business and Management, 7(19), 84.-95.

Famiyeh, S., Asante-Darko, D. \& Kwarteng, A. (2018). Service quality, customer satisfaction, and loyalty in the banking sector. International Journal of Quality \& Reliability Management, 35(8), 1546-1567.

Grönroos, C. (1988). Service quality: The six criteria of good perceived service quality. Review of Business, 9(1), 10-13

Jhandir, S. U. (2012). Customer satisfaction, perceived service quality and mediating role of perceived value. International Journal of Marketing Studies, 4(1), 68-76.

Jin, N., Line, N. D., \& Merkebu, J. (2016). The effects of image and price fairness: A consideration of delight and loyalty in the waterpark industry. International Journal of Contemporary Hospitality Management, 28(9), 1895-1914.

Hart, C. W., Heskett, J. L., \& Sasser, J. W. (1990). The profitable art of service recovery. Harvard business review, 68(4), 148-156.

Hensher, D. A. (2014). The relationship between bus contract costs, use perceived service quality and performance assessment. International Journal of Sustainable Transportation, 8(1), 5-27.

Herington, C., \& Weaven, S. (2007). Can banks improve customer relationships with high quality online services?. Managing Service Quality: An International Journal, 17(4), 404-427.

Husnain, M. \& Akhtar, M. W. (2015). Relationship Marketing and Customer Loyalty: Evidence from Banking Sector in Pakistan. Global Journal of Management and Business Research: E-Marketing, 15(10), 1-15.

Hume, M., \& Sullivan Mort, G. (2010). The consequence of appraisal emotion, service quality, perceived value and customer satisfaction on repurchase intent in the performing arts. Journal of Services Marketing, 24(2), 170-182.

Kangogo, E.J., Musiega, \& Manyasi, J. (2013). Effect of Customer Satisfaction on Performance of the Hotel Industry in the Western Tourism Circuit of Kenya. European Journal of Business and Management, 5(14), 87-100.

Kaura, V., Prasad, Ch. S. \& Sharma, S. (2014). Service quality, service convenience, price and fairness, customer loyalty, and the mediating role of customer satisfaction. International Journal of Bank Marketing, 33(4), 404-422.

Keshavarz, Y., \& Jamshidi, D. (2018). Service Quality Evaluation and the Mediating Role of Perceived Value and Customer Satisfaction in Customer Loyalty. International Journal of Tourism Cities, 4(2), 220-244.

Khuong, M. N., \& Dai, N. Q. (2016). The Factors Affecting Customer Satisfaction and Customer Loyalty — A Study of Local Taxi Companies in Ho Chi Minh City, Vietnam. International Journal of Innovation, Management and Technology, 7(5), 228-233.

Komunda, M., \& Osarenkhoe, A. (2012). Remedy or cure for service failure? Effects of service recovery on customer satisfaction and loyalty. Business Process Management Journal, 18(1), 82-103.

Kumar, A., Olshavsky, R.W., \& King, M.F. (2001). Exploring the antecedents of customer delight. Journal of Consumer Satisfaction, Dissatisfaction and Complaining Behavior, 14, 14-27.

Lai, C. S., \& Nguyen, M. C. (2017). Factors affecting service quality, customer satisfaction and loyalty of mobile phone service providers in Vietnam. International Journal of Organizational Innovation (Online), 10(2), 75-85.

Li, J. (2013). Factors affecting customer satisfaction and customer loyalty towards Belle Footwear Company in Lanzhou City, Gansu Province of the People's Republic of China. IOSR Journal of Business and Management, 14(2), 41-48.

Maxham III, J. G., \& Netemeyer, R. G. (2003). Firms reap what they sow: the effects of shared values and perceived organizational justice on customers' evaluations of complaint handling. Journal of Marketing, 67(1), 46-62. 
Nadler, L. (1970). Developing human resources. Huston TX: Gulf Publishing.

Neupane, R. (2014). Relationship between Customer Satisfaction and Business Performance: A Case Study of Lloyds Bank UK. International Journal of Social Sciences and Management, 1(2), 74-85.

Nguyen, H. T., Nguyen, H., Nguyen, N. D. \& Phan, A. C. (2018). Determinants of customer satisfaction and loyalty in Vietnamese lifeinsurance setting. Sustainability, 10(4), 1151-1167.

Obeidat, Z., Alshurideh, M., Al Dweeri., R. and Masa'deh, R. (2019) The Influence of Online Revenge acts on consumers psychological and emotional states: Does Revenge Taste Sweet? IBIMA Conference proceedings 33 (Granada, Spain).

Obeidat, B., Sweis, R., Zyod, D., \& Alshurideh, M. (2012). The effect of perceived service quality on customer loyalty in internet service providers in Jordan. Journal of Management Research, 4(4), 224-242.

Odunlami, I. B., Olawepo, G.T. \& Emmanuel, A. T., (2013). Effect of customer satisfaction on organizational profitability, using an organization in the food and beverage industry. International Journal of Management Sciences, 1(5), 159-166.

Plassmann, H., Kenning, P., \& Ahlert, D. (2007). Why companies should make their customers happy: The neural correlates of customer loyalty. ACR North American Advances. in NA - Advances in Consumer Research Volume 34, eds. Gavan Fitzsimons and Vicki Morwitz, Duluth, MN : Association for Consumer Research, Pages: 735-739.

Patterson, K. (1997). Delighted clients are loyal clients. Rough Notes, 140(3), 221-34.

Phi, H., Thanh, L. \& Viet, B. (2018). Effects of service quality on customer satisfaction and customer loyalty: A case of 4- and 5-star hotels in Ho Chi Minh City, Vietnam. Business and Economic Horizons, 14(1), 437-450

Rahman, M. H. (2014). Factors Affecting Customer Satisfaction in Mobile Telecommunication Industry in Bangladesh. Business, Management and Education, 12(1), 74-93.

Romdonny, J. \& Rosmadi, M. (2019). Factors affecting customer loyalty in products. Budapest International Research and Critics Institute-Journal (BIRCI-Journal). 2(1), 337-343.

Salvador, C., Rebolloso, E., Fernandez-Ramırez, B. \& Canton, M. (2006). Service price components and their relationship with customer satisfaction. Journal of Revenue and Pricing Management, 6(1), 40-50.

Salloum, S. A., \& Al-Emran, M. (2018). Factors affecting the adoption of E-payment systems by university students: Extending the TAM with trust. International Journal of Electronic Business, 14(4), 371-390.

Salloum, S. A., Al-Emran, M., Shaalan, K., \& Tarhini, A. (2019). Factors affecting the E-learning acceptance: A case study from UAE. Education and Information Technologies, 24(1), 509-530.

Salloum, S. A., \& Shaalan, K. (2018, September). Adoption of e-book for university students. In International Conference on Advanced Intelligent Systems and Informatics (pp. 481-494). Springer, Cham.

Salloum, S. A. S., \& Shaalan, K. (2018). Investigating students' acceptance of E-learning system in Higher Educational Environments in the UAE: Applying the Extended Technology Acceptance Model (TAM). The British University in Dubai.

Salloum, S. A., Alhamad, A. Q. M., Al-Emran, M., Monem, A. A., \& Shaalan, K. (2019). Exploring Students' Acceptance of E-Learning through the Development of a Comprehensive Technology Acceptance Model. IEEE Access, 7, 128445-128462.

Salloum, S. A., Al-Emran, M., \& Shaalan, K. (2018, August). The impact of knowledge sharing on information systems: A review. In International Conference on Knowledge Management in Organizations (pp. 94-106). Springer, Cham.

Schiffman, L.G. and Kanuk, L.L. (2004), Consumer Behavior, Prentice Hall, Upper Saddle River, NJ.

Shafei, I. \& Tabaa, H. (2016). Factors affecting customer loyalty on mobile telecommunications industry. EuroMed Journal of Business, $11(3), 347-361$

Shannak, R., Masa'deh, R., Al-Zu'bi, Z., Obeidat, B., Alshurideh, M., \& Altamony, H. (2012). A theoretical perspective on the relationship between knowledge management systems, customer knowledge management, and firm competitive advantage. European Journal of Social Sciences, 32(4), 520-532.

Suki, N. M. (2014). Passenger satisfaction with airline service quality in Malaysia: A structural equation modeling approach. Research in Transportation Business \& Management, 10, 26-32.

Solimun, S., \& Fernandes, A.A. (2018). The mediation effect of customer satisfaction in the relationship between service quality, service orientation, and marketing mix strategy to customer loyalty. Journal of Management Development, 37(1), 76-87

Tam, J. L. (2004). Customer satisfaction, service quality and perceived value: an integrative model. Journal of Marketing Management, 20(7-8), 897-917.

Tjiptono, F. (2002), Marketing Strategy, Publisher Andi, Yogyakarta.

Toncar, M., Alon, I. \& Misati, E. (2010). The importance of meeting price expectations: linking price to service quality. Journal of Product \& Brand Management, 19(4), 295-305.

Torres, E. N., \& Kline, S. (2006). From satisfaction to delight: a model for the hotel industry. International Journal of Contemporary Hospitality Management, 18(4), 290-301.

Torres, E., \& Kline, S. (2013). From customer satisfaction to customer delight: Creating a new standard of service for the hotel industry. International Journal of Contemporary Hospitality Management, 25(5), 642-659.

Yallapragada, P. (2017). Determinants of Customer Satisfaction in the Mobile Telecommunications Services Among the University Students in Dubai. Advance Research Journal of Multi-Disciplinary Discoveries, 12(1), 5-11.

Zameer, H., Wang, Y., Yasmeen, H. \& Ahmed, W. (2019). Modeling the role of service quality, customer satisfaction and customer loyalty in building service brand equity. International Journal of Asian Business Information Management, 10(2), 55-72.

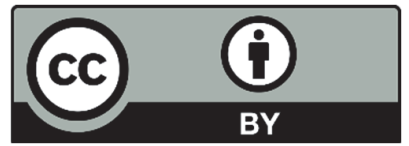

(C) 2020 by the authors; licensee Growing Science, Canada. This is an open access article distributed under the terms and conditions of the Creative Commons Attribution (CC-BY) license (http://creativecommons.org/licenses/by/4.0/). 